\title{
GENETIC DIVERSITY OF AMPICILLIN-RESISTANT Vibrio ISOLATED FROM VARIOUS STAGES OF TIGER SHRIMP LARVAE DEVELOPMENT
}

\author{
WIDANARNI ${ }^{\mathrm{a}}$ AND ANTONIUS SUWANTO ${ }^{\mathrm{bc}}$ \\ "Department of Aquaculture, Faculty of Fisheries and Marine Science \\ Bogor Agricultural University, Bogor 16680, Indonesia \\ ${ }^{\mathrm{b}}$ Department of Biology, Faculty of Science and Mathematics, \\ and IUC Biotechnology, Bogor Agricultural University, Bogor 16680, Indonesia \\ 'SEAMEO-BIOTROP, JI. Raya Tajur, Km 6 Bogor, Indonesia
}

\begin{abstract}
This research was carried out to study genetic diversity of ampicillin-resistant Vibrio from various stages of tiger shrimp larvae (Penaeus Monodon) development from,Tambak Inti Rakyat hatchery, near Labuan, West Java, Indonesia. A total of 25 ampicillin-resistant Vibrio isolates were isolated using thiosulphate citrate bile-salt sucrose agar (TCBS-Agar) and seawater complete agar (SWC-Agar). Physiological and biochemical characterization showed that the isolates could be grouped into only two species, i.e. $V$. harveyi from the egg stage; and $V$. metschnikovii from larvae

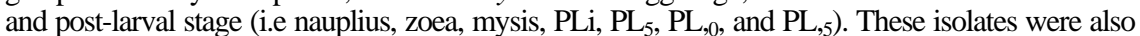
present in their respective rearing water of each stage and some natural feed. Schizotyping analysis employing restriction endonuclease Noll (5'-GC4GGCCGC) indicated that the isolates could be grouped into at least 13 different genotypes. Therefore, schizotyping was more discriminative than physiological characterization. This study showed that particular groups of Vibrio colonized all stages of shrimp larvae and demonstrated closed phylogenetic relationship. These groups of Vibrio might be the dominant microbiota which could suppress the development of other Vibrio including the pathogenic Vibrio.
\end{abstract}

Key words : Shrimp/ampicillin-resistant K/fcno/schizotyping

\section{INTRODUCTION}

Tiger shrimp (Penaeus monodori) culture has developed towards intensive levels due to high demand and significant price of this commodity. However, recently shrimp production has decreased significantly because of diseases and poor environment quality (Anonymous 1994). One of the most serious problems is the disease caused by Vibrio (Lavilla-Pitogo et al. 1990). The disease greatly influenced the sustainable supply of healthy fry (Lightner et al. 1992).

Hameed (1993) observed that the decrease of survival rate of larvae and postlarvae was due to the concomitant increase of the bacteria population. Generally, shrimps at the stadia of zoea, mysis, and the beginning of post-larvae were vulnerable to Vibrio infection (Rukyani et al. 1992). It was believed that these bacteria contaminated the hatchery through broodstock feces because of their presence in significant number in the midgut (Lavilla-Pitogo et al. 1990). Therefore,

\footnotetext{
* Corresponding author : email address : asuwanto@indo.net.id;Fax : 62-251-315107
} 
contamination of the eggs and nauplius by these bacteria was highly probable. Besides the infected shrimp, these bacteria could also be isolated from seawater used for rearing water in the hatcheries (Tjahjadi et al. 1994). Recently, Suwanto et al. (1998) demonstrated that Vibrio harveyi isolated from different broodstocks were genetically very diverse and different to each other. Therefore, it can be expected that vertical infection from broodstock to eggs is more likely to occur rather than horizontal transfer from larvae to larvae. In order to understand genetic diversity of Vibrio at various stages of shrimp larvae development, a study on genetic diversity of Vibrio isolated from egg, larvae, and post-larvae of shrimp originated from the same broodstock was carried out.

A number of techniques have been developed to identify bacteria at the subspecies level. These include phage typing (Stringer 1980), analyses of plasmid DNA (Davies et al. 1981), ribotyping (Olsen et al. 1986), Random Amplified Polymorphic DNA (RAPD) (Welsh and McClelland 1990), and schizotyping by pulsed-field gel electrophoresis (PFGE) (Suwanto and Kaplan 1992). PFGE analysis of large sizes of DNA molecules requires a technique to isolate intact genomic DNA as well as the availability of rare-cutting restriction endonucleases and the appropriate mega-base molecular size markers. Under optimized condition, PFGE can efficiently separate DNA fragments of 100 to $10,000 \mathrm{kbp}$ to distinguish strains of microorganisms which otherwise exhibit similar or identical physiological and morphological characteristics (Suwanto 1994).

Genetic diversity analysis based upon genomic DNA profile utilizing PFGE has been performed for various bacteria for various aims, such as Vibrio anguil-larum, a causative agent of vibriosis in fish (Skov et al. 1995), genomic DNA analysis of Xanthomonas campestris, a causative agent of root-pustule disease of soybean (Rukayadi 1995) and Vibrio harveyi, a causative agent of "luminous-bacterial disease" (Suwanto et al. 1998). PFGE genomic DNA analysis used in the experiments above have proved to be more discriminative to visualize phylogenetic diversity rather than analysis based on phenotype characterization.

The purpose of this research was to study the genetic diversity of ampicillin-resistant Vibrio from various stages of shrimp larvae development by PFGE analyses.

\section{MATERIALS AND METHODS}

\section{Isolation and identification of Vibrio sp.}

Vibrio were isolated from eggs, larvae (nauplius, zoea, and mysis), and post-larvae (PL, $\mathrm{PL}_{5}, \mathrm{PL}_{10}$, and $\mathrm{PL}_{15}$ ) of tiger shrimp (P. monodori), natural shrimp feed (i.e. Anemia and Skeletonema), and rearing water obtained from Tambak Inti Rakyat hatchery, near Labuan, West Java, Indonesia. Shrimp larvae were collected in the month of March-April, 1998. Five eggs and shrimp larvae were washed gently in sterile seawater and collected into a test tube containing $1 \mathrm{ml}$ sterile seawater, and homogenized by Vortex agitator before it was spread on TCBS agar. Appropriate 
dilution was performed to obtain single isolated colony on TCBS agar by adding sterile seawater. The culture was incubated at room temperature, $(28-31)^{\circ} \mathrm{C}$, for 24 hours. Isolated colonies were randomly selected for further study. Biochemical and physiological characterization were conducted with Microbact ${ }^{\mathrm{R}}$ Analysis kit (Medved Science Pty. Ltd. Australia). Identification of Vibrio isolates were done as described by Baumann et al. (1984). Seawater complete agar (5 g bactopeptone, $1 \mathrm{~g}$ yeast extract, 3 $\mathrm{ml}$ glycerol, $15 \mathrm{~g}$ agar, $750 \mathrm{ml}$ seawater, and $250 \mathrm{ml}$ distilled water) supplemented with ampicillin (50 ug/ml) (SWC-Ap) was employed as a selective media to screen for ampicilin-resistant Vibrio isolates. The isolates were subsequently suspended in sterile seawater containing $15 \%$ glycerol $(\mathrm{v} / \mathrm{v})$ before they were stored in the freezer at $-50^{\circ} \mathrm{C}$.

\section{Preparation of intact genomic DNA and digestion}

Purified isolates of ampicillin-resistant Vibrio were grown in SWC agar. One separated colony was regrown in $10 \mathrm{ml}$ LB medium (10 g tryptone, 5 g yeast extract, 25 $\mathrm{gNaCl}$ and $1 \mathrm{~L}$ distilled water) at $28^{\circ} \mathrm{C}$ overnight. One $\mathrm{ml}$ of bacterial suspension was centrifuged at 5,000 rpm for 30 seconds. The bacterial cell pellet was suspended in sterile PIV solution (10 mM Tris-Cl pH 7.5, $1 \mathrm{M} \mathrm{NaCl}$ ). Preparation of intact genomic DNA was performed by embedding the bacterial cells in low melting aga-rose blocks as described previously (Schwartz and Cantor 1984). Digestion of the intact genomic DNA was done using restriction enzyme as described by Suwanto et al. (1998) as follows: digestion with 10 units of Notl were performed in $150 \mathrm{ml}$ of appropriate restriction buffer (1335 ul distilled water, $150|i|$ lOx restriction buffer, 15 ul of $10 \mathrm{mg} / \mathrm{ml}$ bovine serum albumine). The mixture was incubated at $4^{\circ} \mathrm{C}$ for 15 minutes followed by incubation in $37^{\circ} \mathrm{C}$ overnight. Dialysis of the gel plugs were performed by immersing the gel plugs in excess of Ix TE buffer solution $(10 \mathrm{mM}$ Tris-Cl pH 8.0, 1 mM EDTA pH 8.0) before placing the gel plugs into the wells of the running gel.

\section{Separation of DNA fragment using PFGE}

The running gels of $1 \%(\mathrm{w} / \mathrm{v})$ agarose (Pharmacia) were prepared in $100 \mathrm{ml}$ of 0.5x TBE (50 mM Tris-Borate buffer, $0.1 \mathrm{mM}$ EDTA pH 8.0). Pulsed-field gel electrophoresis was performed using CHEF-DRII (Bio Rad, Richmond, CA). The gels were run in $0.5 \mathrm{x}$ TBE buffer, 5 volt, $14^{\circ} \mathrm{C}$ with ramping pulse time from 10-80 seconds for 20 hours. As molecular marker, Rhodobacter sphaeroides 2.4.1 genomic digested with Asel was routinely used for PFGE (Suwanto and Kaplan 1989).

\section{DNA visualization}

Gels were stained by submerging in ethidium bromide solution $(1 \mathrm{ug} / \mathrm{ml})$ for 10 minutes. Destaining were done in distilled water for 20-30 minutes. Transillu-minator with UV length of $280 \mathrm{~nm}$ (Hoefer Scientific Instrument, San Francisco) 
BIOTROPIA NO. 15, 2000

was used to visualize the gel. Photographs were taken with fast film polaroid (Type 667, Japan Polaroid Company).

\section{Statistical analysis}

A matrix was constructed as the basis for determining the presence or absence of schizotyping bands at a given position over the size range from 30-500 kb. A cluster analysis was carried out using the unweighed pair group method with arithmetic means (UPGMA clustering with simple matching coefficient) of similarity coefficient for all pairs of strain and a dendrogram was generated using a computer-based taxonomy program (Numerical Taxonomy System, NTSYS-PC version 1.60) (Rohlf 1990).

\section{RESULTS AND DISCUSSION}

\section{Physiological and biochemical characterization of Vibrio isolates}

Twenty five ampicillin-resistant isolates have been isolated and selected randomly from either TCBS or SWC-Ap for further study (Table 1). Of these isolates, 20 isolates were found to be associated with eggs, larvae, post-larvae, and the rearing water of each stage; two isolates were isolated from seawater reservoir; and the other isolates were obtained from natural feed (i.e. Artemia and Skeletonema).

Table 1. Codes and sources of Vibrio isolates

\begin{tabular}{|c|l|l|c|c|c|}
\hline No. & Code & Source & No. & Code & Source \\
\hline 1. & E, & Egg & 14 & ST & Broodstock tank water \\
\hline 2. & $\mathrm{E}_{2}$ & Egg & 15. & $\mathrm{ET}$ & Spawning tank water \\
\hline 3. & $\mathrm{~N}$ & Nauplius & 16. & $\mathrm{NT}$ & Nauplius tank water \\
\hline 4. & $\mathrm{Z}$ & Zoea & 17. & $\mathrm{ZT}$ & Zoea tank water \\
\hline 5. & $\mathrm{M}$, & My sis & 18. & $\mathrm{MT}$ & Mysis tank water \\
\hline 6. & $\mathrm{M}_{2}$ & Mysis & 19. & $\mathrm{PL}, \mathrm{T}$ & Post-larvae 1 tank water \\
\hline 7. & $\mathrm{M}_{3}$ & Mysis & 20. & $\mathrm{P}_{5} \mathrm{~T}$ & Post-larvae 5 tank water \\
\hline 8. & $\mathrm{PL}$, & Post-larvae 1 & 21. & $\mathrm{PL}, 0_{0} \mathrm{~T}$ & Post-larvae 10 tank water \\
\hline 9. & $\mathrm{PL} 5$ & Post-larvae 5 & 22. & $\mathrm{PL}_{15} \mathrm{~T}$ & Post-larvae 15 tank water \\
\hline 10. & $\mathrm{PL}, 0$ & Post-larvae 10 & 23. & $\mathrm{SKT}$ & Skeletonema \\
\hline 11. & $\mathrm{PL}$, & Post-larvae 15 & 24. & $\mathrm{AT}$, & Artemia \\
\hline 12. & $\mathrm{SW}$, & Sea water & 25. & $\mathrm{AT}_{2}$ & Artemia \\
\hline 13. & $\mathrm{SW}$ & Sea water & & & \\
\hline
\end{tabular}


Physiological and biochemical characterization showed that the isolates shared several similar characters. The cell was rod shape, produced lysine decarboxylase and indole, and all were able to ferment glucose (Table 2). The isolates could be classified into three groups. First group, composed of E, $\mathrm{E}_{2}$, $\mathrm{M}, \mathrm{SW}, \mathrm{SW}_{2}$, and $\mathrm{MT}$ shared the same characters such as: forming green colonies on TCBS, oxidase-positive, produce protease and chitinase, and able to reduce nitrate. A number of isolates were also able to utilize arabinose as a carbon source. The second group of Vibrio composed of only one isolate, $\mathrm{AT}_{2}$ isolated from Anemia had the same characters as first group except that it was luminous. The third group (N, Z, M2, PL, PL,5, ET, ZT, PL ${ }_{5} T, \mathrm{PL}_{10} \mathrm{~T}, \mathrm{SKT}, \mathrm{AT}$,), was the dominant group of the isolates found in every larval stage except the eggs possessed completely different characters from the two groups in having nonluminous yellow colonies on TCBS, showed negative oxidase reaction, did not produce protease and chitinase, and were able to use sucrose as a carbon source.

Based upon Baumann et al. (1984) identification, the first group was non-luminous $V$. harveyi, the second was luminous $V$. harveyi, and the third was $V$. metschnikovii. Therefore, physiological characterization of Vibrio isolated from each stage from Tambak Inti Rakyat hatchery, West Java, showed that two species of Vibrio had been found. $V$. harveyi were associated with eggs, while $V$. metschnikovii were found in larvae and post-larvae (nauplius, zoea, mysis, PL, $\mathrm{PL}_{5}$, PL,o, and $\mathrm{PL}_{15}$ ), These isolates were also present in their respective rearing water of each stage and some natural feed.

\section{Schizotyping analysis}

PFGE electrophoresis of the 25 Vibrio isolates (obtained in this study) and of $V$. harveyi S14B (Suwanto et al. 1998) using Notl restriction enzyme (Figure 1) showed discrete profiles of genomic DN A of the isolates based upon the number of fragments and migration distance (Table 3). Restriction with Notl produced 10-16 discrete DNA fragments with sizes ranging from 31-910 kb. Genomic DNA analysis of 25 isolates showed 13 different DNA profiles. These DNA profiles could be used as a unique fingerprint of each of those isolates.

Dendrogram of genomic DNA digested with Notl (Figure 2) showed genetic relatedness of the isolates, which could be divided into 13 different subgroups. The sum of horizontal lines connecting the two isolates indicated genetic distance of those isolates. For example, the distance between isolate $\mathrm{PL} \mid$ and $\mathrm{PL}_{5}$ is zero indicated that these isolates are identical. Of these, 13 subgroups were divided into 2 major groups. The first major group consisted of 20 isolates associated with all stages of shrimp larvae and their rearing water. The second group consisted of 5 isolates, i.e. 2 isolates from seawater reservoir, 1 isolate from broodstock rearing water, and 2 isolates from natural feed (Skeletonema and Anemia). Some Vibrio isolates originated from seawater and natural feed also could not be isolated from all larvae stages and eggs of shrimp. This result suggested that eggs were exposed to bacterial contamination not only from broodstock feces as reported by Lavilla 
BIOTROPIA NO. 15, 2000

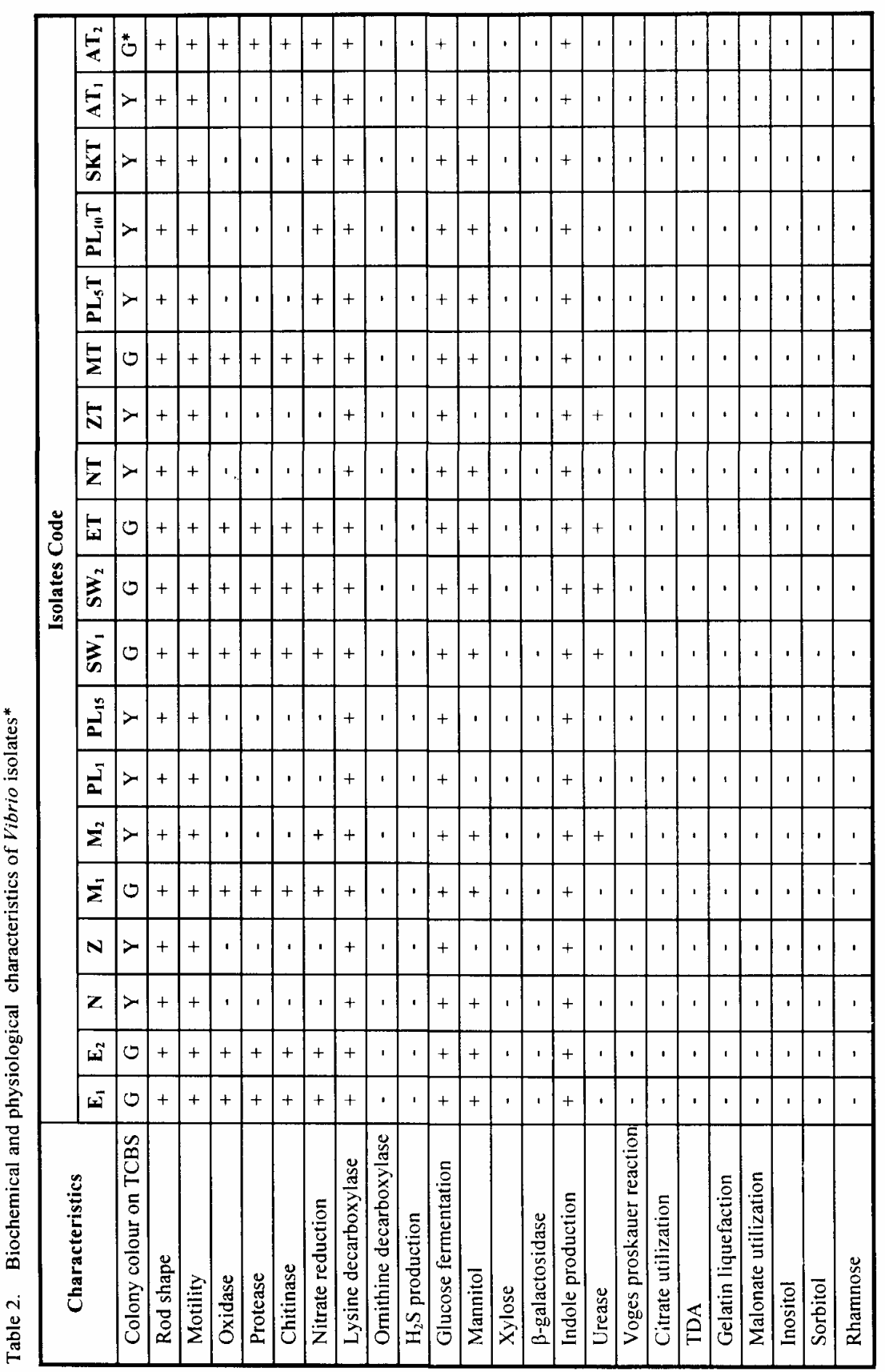


Genetic diversity of ampiciloin-resistand Vibro - Widanarni \& Antonius Suwanto

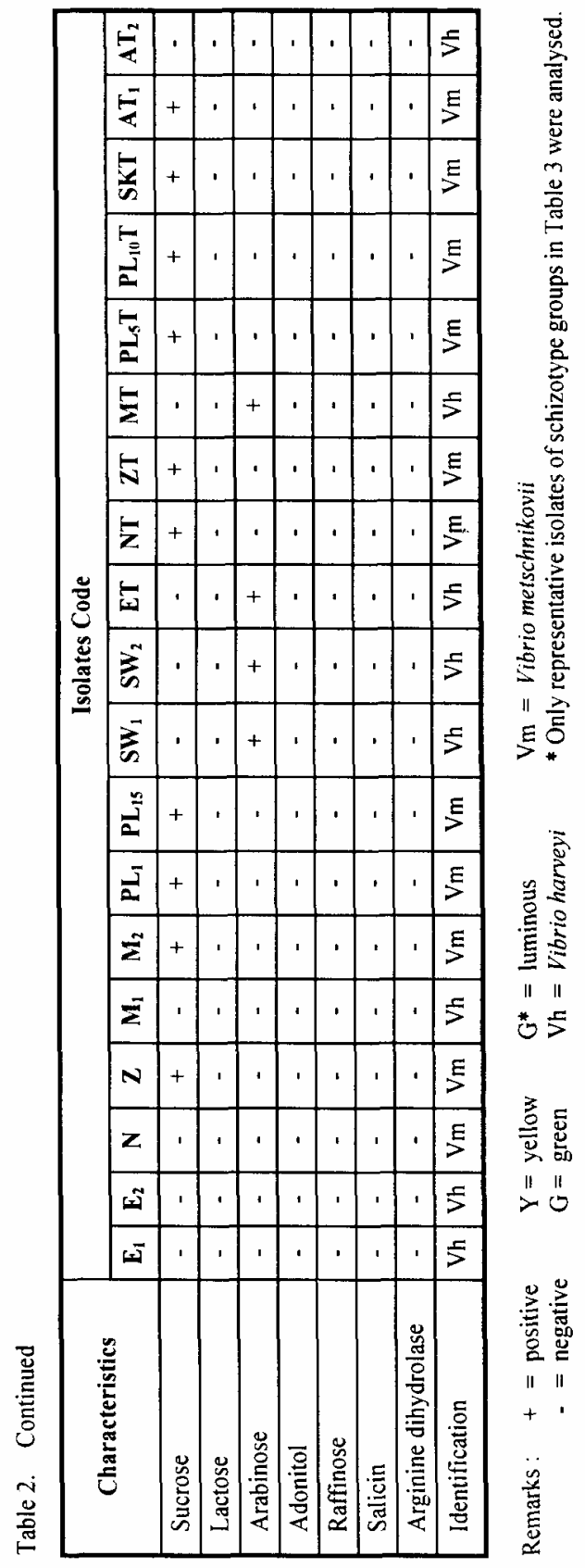


BIOTROPIA NO. 15, 2000

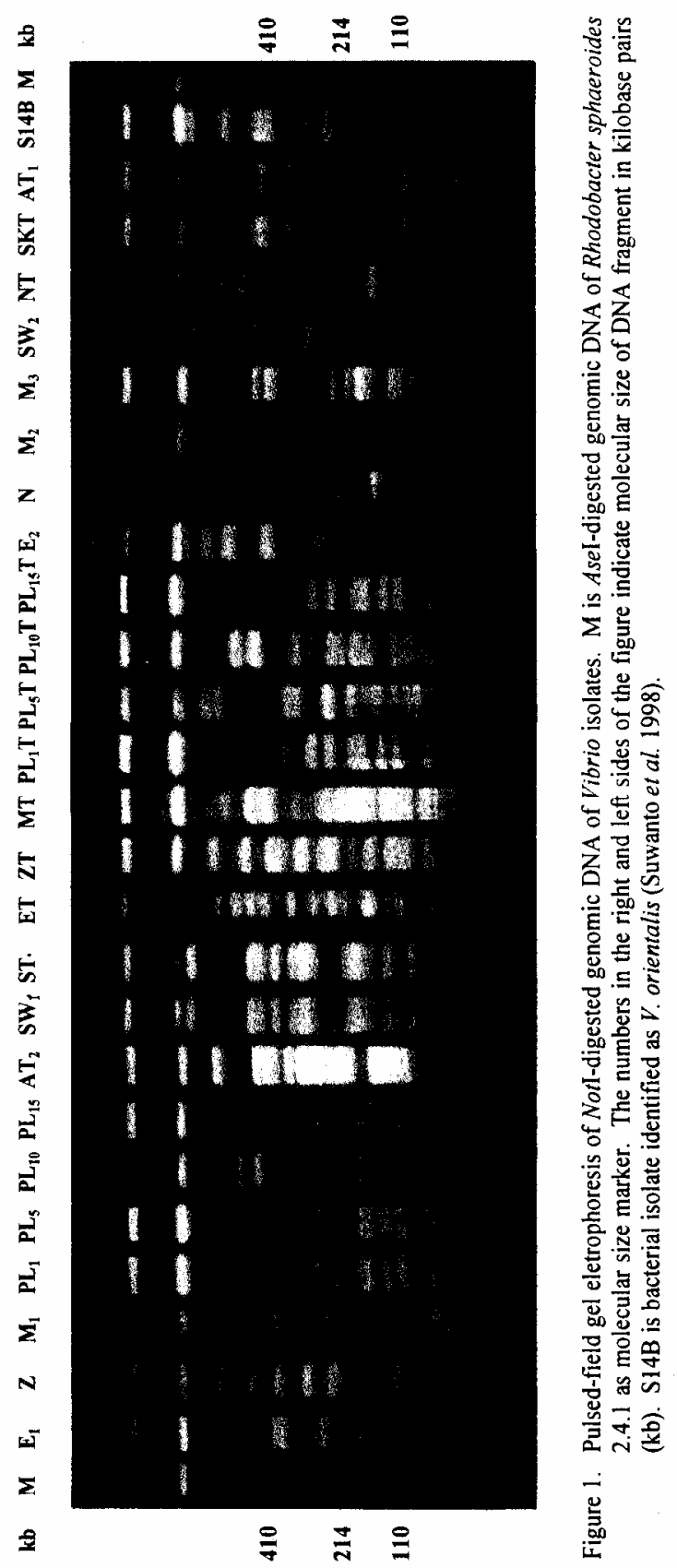


Genetic diversity of ampicillin-resistant Vibrio - Widanarni \& Antonius Suwanto

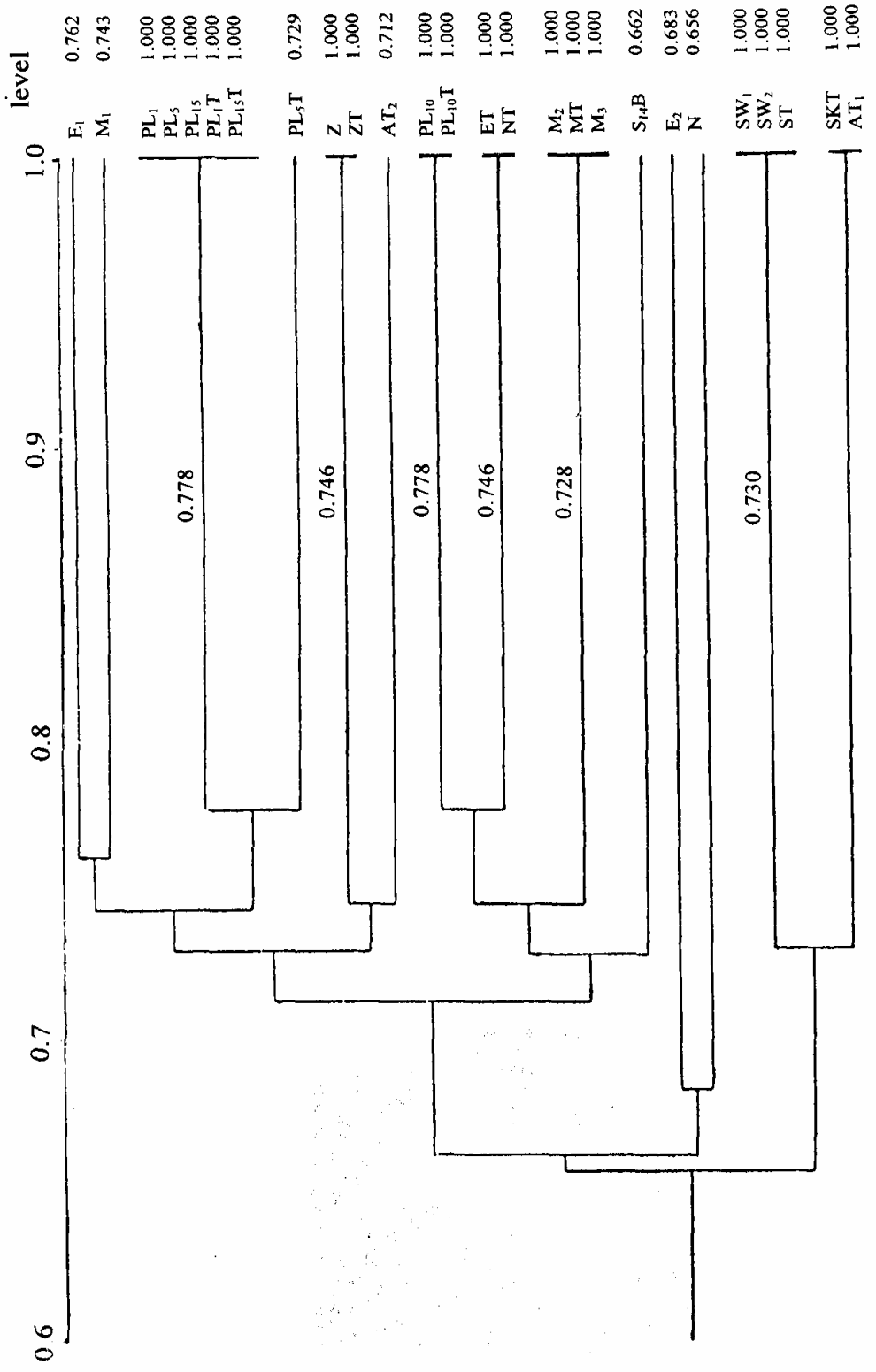

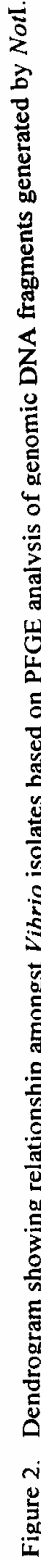


Table 3. Grouping of genomic DNA profiles of 25 Vibrio isolates generated by Noll schizo typing

\begin{tabular}{|c|c|c|}
\hline 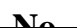 & & lot \\
\hline 1. & E, & E, \\
\hline 2. & $\mathrm{M}$, & $\mathrm{M}$, \\
\hline 3. & PL, & PL, PL,5, PL,T, PL, ,T \\
\hline 4. & $\mathrm{PL}_{5} \mathrm{~T}$ & $\begin{array}{l}\text { PL,T } \\
\end{array}$ \\
\hline 5. & $\mathrm{Z}$ & $\mathrm{ZT}$ \\
\hline 6. & $\mathrm{AT}_{2}$ & $\mathrm{AT}_{2}$ \\
\hline 7. & PL,0 & $\mathrm{PL}_{\mathbb{I} 1 \mathrm{~T}} \mathrm{~T}$ \\
\hline 8. & ET & NT \\
\hline 9. & $M_{2}$ & MT, M, \\
\hline 10. & $E_{2}$ & $\mathrm{Ea}$ \\
\hline 11. & $\mathrm{~N}$ & $\mathrm{~N}$ \\
\hline 12. & SW, & $\mathrm{SW}_{2} \mathrm{ST}$ \\
\hline 13. & SK.T & AT, \\
\hline
\end{tabular}

Pitogo et al. (1990), but also when they were still in the ovary. Our study also demonstrated that Vibrio isolates from sea water or natural feed possessed distance genetic relationship to that of Vibrio from eggs and larvae, indicating that Vibrio from eggs and larvae may be the dominant microbiota and might play a role in suppressing the growth of Vibrio from seawater or natural feed.

Compared to the results of Suwanto et al. (1998), all of Vibrio isolates in this experiment showed relatively similar genetic background. This might be due to the fact that the broodstocks in this study were obtained from the same area (Aceh province), while Suwanto et al. (1998) used broodstocks from different areas and provinces.

This study showed that genetic analysis by PFGE was more discriminative than that of physiological and biochemical analysis. From 25 isolates characterized by physiological analysis, they could be grouped into two species, while using schizotyping analysis, there were 13 different groups of genotypes. Furthermore, with this analysis, V. metschnikovii, that did not produce protease and chitinase was apparently closely related to $V$. harveyi, a shrimp pathogen. Therefore, the existence of V.metchnikovii might influence shrimp larval fitness and survival.

In conclusion, physiological and biochemical characterization were able to classify 25 isolates Vibrio (both luminous and non-luminous) into two species, i.e. $V$. harveyi and $V$. metchnikovii. Notl schizotyping analysis showed that the isolates consisted of at least 13 different genotypes, which indicated that schizotyping was 
more discriminative than physiological characterization. The result also demonstrated that Vibrio isolates present in all stages of shrimp larvae showed close phylogenetic relationship. These groups of Vibrio might be dominant and might play a role in suppressing the development of other Vibrio originated from sea water, broodstock feces or natural shrimp feed.

\section{ACKNOWLEDGEMENTS}

We express our thanks to Tambak Inti Rakyat Hatchery, Labuan, West Java, for supplying shrimp larvae and to allow us to use the field laboratory facility. We would like also to thank Prof. Dr. Maggy T. Suhartono and Dr. Dwi Andreas Santosa for their invaluable advice during the experiment. This research was supported by Riset Unggulan Kemitraan (RUK) research grant to Antonius Suwanto and Biaya Pendidikan Pasca Sarjana (BPPS) research grant to Widanarni.

\section{REFERENCES}

Anonymous. 1994. Problem solution alternatives of shrimp culture in Java. Directorate General of Fisheries. Jakarta.

Baumann P, Furniss AL, Lee JV. 1984. Facultative anaerobic gram negative rods. In: Krieg NR (ed) Bergey's Manual of Systematics Bacteriology. Williams and Wilkins, Baltimore, MA. Vol. 1:

1513-1523.

Davies FL, Underwood HM, Gasson MJ. 1981. The value of plasmid profiles for strain identification in lactic streptococci and the relationship between Streptococcus lactis 712, ML3 and C2. J Appl Bacteriol 51: 325337.

Hameed ASS. 1993. A study of the aerobic heterotrophic bacterial flora of hatchery-reared eggs, larvae and postlarvae ofPenaeus indicus. Aquaculture 117:195-204.

Lavilla-Pitogo CR, Baticados CL, Cruz-Lacierda ER, de la Pena LD. 1990. Occurrence of luminous bacterial diseases of Penaeus monodon larvae in the Philippines. Aquaculture 91:1-13.

Lightner DV, Bell TA, Redman RM, Mohney LL, Natividad JM, Rukyani A, Poemomo A. 1992. A review of some major diseases of economic significance in penaeid prawn/shrimp of the Americans and Indopacific. In: Shariff M, Subasinghe RP, Arthur JR (eds). Diseases in Asian Aquaculture 1. Fish Health Section. Asean Fisheries Society. Manila, Philippines p.57-80.

Olsen GJ, Lane DJ, Gionvannoni SJ, Pace NR. 1986. Microbial ecology and evolution: a ribosomal RNA approach. Ann Rev Microbiol 40: 337-365.

Rohlf FJ. 1990. NT-Sys-pc, Numerical taxonomy and multivariate analysis system, version 1.60. Exeter Software, New York.

Rukayadi Y. 1995. DNA profile analysis of the genomes of a number of Xanthomonas campestris pv. glycines isolates using Pulsed-field gel Electrophoresis. Thesis Pascasarjana Program, IPB. Bogor. 69p.

Rukyani A, Taufik P, Taukhid 1992. Luminous vibrios in tiger shrimp hatchery and the control of the disease in shrimp larvae. J. Litbang Pertanian 2:1-17. 
Schwartz DC, Cantor CR. 1984. Separation of yeast chromosome-sized DNA by pulsed-field gradient gel electrophoresis. Cell 37:67-75.

Skov MM, Pedersen K, Larsen JA. 1995. Comparison of pulsed-field gel electrophoresis, ribotyping, and plasmid profiling for typing of Vibrio anguillantm serovar Ol. App and Env Microbiol 61:1540-1545.

Stringer J. 1980. The development of a phage typing system for group B streptococci. J Med Microbiol 13:133-143.

Suwanto A, Kaplan S. 1989. Physical and genetic mapping of Rhodobacler sphaeroides 2.4.1 genome: genome size, fragment identification and gene localization. J Bacteriol 171:1135-1145.

Suwanto A, Kaplan S. 1992. Chromosome transfer in Rhodobacter sphaeroides: Hfr formation and genetic evidence for two unique circular chromosomes. J Bacteriol 174:1135-1145.

Suwanto A. 1994. Pulsed-field gel electrophoresis: a revolution in microbial genetics. As Pac J Mol Biotechnol 2:78-85.

Suwanto A, Yuhana M, Herawaty E, Angka SL. 1998. Genetic diversity of luminous Vibrio isolated from shrimp larvae In: Flegel TW (ed) Advances in shrimp biotechnology. National Center for Genetic Engineering and Biotechnology, Bangkok, p 2-9.

Tjahjadi MR, Angka SL, Suwanto A. 1994. Isolation and evaluation of marine bacteria for biocontrol of luminous bacterial disease in tiger shrimp larvae (Penaeus monodon, Fab.). As Pac J Mol Biol Biotechnol 2:347-352.

Welsh J, Me Clelland M. 1990. Fingerprinting genomes using PCR with arbitrary primers. Nucleic Acids Res 18:7213-7218. 